„Kwartalnik Filmowy” nr 113 (2021)

ISSN: 0452-9502 (Print) ISSN: 2719-2725 (Online)

https://doi.org/10.36744/kf.725

(C) Creative Commons BY-NC-ND 4.0

Grażyna Stachówna

Uniwersytet Jagielloński

https://orcid.org/0000-0002-7288-6803

\title{
Alicja już tu nie mieszka...
}

\author{
Słowa kluczowe: \\ Alicja Helman
}

\author{
Abstrakt \\ Wspomnienie o Profesor Alicji Helman (1935-2021).
}

Alicja zerwała się i pobiegła, a biegnac myślata o tym,
jak cudowny byt to sen.
Lewis Carroll, Przygody Alicji w Krainie Czarów,
tłum. Maciej Słomczyński

Przed laty na ścianie krakowskiej kamienicy stojącej przy alei Słowackiego, gdzie mieściło się mieszkanie Pani Profesor Alicji Helman, jakiś anonimowy dowcipniś napisał wielkimi białymi literami Alicja już tu nie mieszka. Wspaniale połączył wiedzę filmoznawcza, bo to przecież tytuł filmu Martina Scorsese z 1974 r., $\mathrm{z}$ informacją że najważniejszą osobą $\mathrm{w}$ tym budynku (zapełnionym profesorami Uniwersytetu Jagiellońskiego) jest właśnie ona, Alicja, i ze złośliwym poczuciem humoru, bo znałam ludzi, którzy idąc z pierwszą wizytą do Pani Profesor, uznawali ten naścienny napis za obowiązujący i rezygnowali ze spotkania.

Mieszkanie Pani Profesor "na Alejach" - wielkie i zawsze życzliwie otwarte - ileż ewokuje wspomnień! Lubiła zapraszać do siebie ludzi, szczególnie swoich współpracowników i uczniów, wśród których czuła się najlepiej, jakby ich młodość i żarliwość dodawały jej życiowej energii. W zamian oferowała swój czas, uwagę, dobre rady, wsparcie w trudnych chwilach i świetną wyżerkę - bo wspaniale gotowała - a jej cielęcina z rydzami była prawdziwym poematem. „Na Alejach” odbywały się zebrania naukowe, narady nad pisanymi pracami, sesje plotkarskie 
z przyjaciółkami, bale filmoznawców - jakich zazdroszczono nam na Uniwersytecie - na których Pani Profesor podawała mocne koktajle o wyszukanych nazwach, z zabójczym „Pies bez zmysłów pada” (to cytat z Indyka Mrożka) na czele. Koty - dorodne, leniwe, rozpieszczone - Pani Profesor je uwielbiała. W 1995 r. na konferencji Wstydliwe przyjemności, czyli po co - tak naprawdę-chodzimy do kina, której temat Pani Profesor wymyśliła (Rzucam pomyst, a wy go tapcie! - mawiała), a ja ją zorganizowałam, wygłosiła efektowny referacik o filmowych kotach zatytułowany Gdy przychodzi kot. Przez wiele lat przyznawała co roku prestiżową Nagrodę Kota Bursztyna (koperta, całusy i bankiet) wyróżniającym się młodym filmoznawcom.

Pani Profesor umiała się przyjaźnić. Lubiła ludzi, a szczególnie swój „fraucymer Alicji" - nazwę wymyśliła pewna zazdrośnica, która nie potrafiła dopasować się do tego klubu - czyli grupę kobiet i dziewcząt z różnych ośrodków akademickich, z którymi chętnie spędzała czas, chodziła do kin i do teatrów, jadała obiady w krakowskich restauracjach, spacerowała w Lasku Wolskim, którym bezinteresownie doradzała w sprawach naukowych, pisała recenzje wydawnicze, wspierała w sprawach życiowych, pouczała przykładami ze swego bogatego życia, czasem pożyczała pieniądze, a przede wszystkim z którymi rozmawiała, rozmawiała i rozmawiała. Oczywiście miała też ludzi niechętnych, bo któż ich nie ma, ale zawsze powtarzała: Obrażają się tylko kucharki - wyborna to maksyma na życie.

Było tajemnicą Pani Profesor, jak znajdowała czas na pisanie własnych, nader licznych książek i artykułów (zawsze pisała ręcznie i dawała teksty do przepisania najpierw na maszynie, później na komputerze), referatów konferencyjnych, na lekturę rozpraw naukowych i grubych powieści pochłanianych dla przyjemności, na tłumaczenia, uważne czytanie i korygowanie prac swych wychowanków (nigdy nie odmawiała pomocy), na pisanie recenzji, oglądanie filmów, uczestniczenie $\mathrm{w}$ różnych imprezach kulturalnych i na życie osobiste. Zawsze podziwiałam jej niezwykłą umiejętność skupiania się na pracy, na tym, czym się akurat zajmowała. Najbardziej lubiła pisać i rozmawiać z ludźmi, nie przepadała za wykładami uniwersyteckimi, męczyły ją.

W obrębie filmoznawstwa Pani Profesor zajmowała się wieloma sprawami. Różnorodność jej dorobku naukowego przyprawia o zawrót głowy: poważne rozprawy naukowe poświęcone historii i teorii filmu (z dziesięciotomowym Słownikiem pojęć filmowych na czele, do którego napisała większość haseł), książki popularne i podręczniki. Muzyka w filmie (z wykształcenia była muzykologiem), monografie Kurosawy, Saury, Viscontiego, Zhanga Yimou, Chena Kaige, historia filmu gangsterskiego, 100 arcydzieł kina, problemy adaptacji filmowych (Twórcza zdrada) i redakcja naukowa serii książek poświęconych adaptacjom dzieł z różnych literatur narodowych... Ostatnią książką jaką na szczęście zdążyła ukończyć, jest ponadsześćsetstronicowa rozprawa o filmowych adaptacjach powieści Thomasa Manna.

Pani Profesor była twórczynią współczesnego polskiego filmoznawstwa jako samodzielnej dyscypliny naukowej oderwanej od polonistyki, do której na początku przypisano wiedzę o filmie. Dotyczyło to nie tylko wyznaczanych horyzontów naukowych, ale także umiejętności gromadzenia wokół siebie młodych, zdolnych ludzi, których karierom patronowała, była ich idealnym tutorem, opiekunem akademickim. Żartowała, że marzeniem jej życia jest pozamykanie nas w celach, „podawanie jedzenia na kiju” i odbieranie zapisanych kartek aż do ukończenia zamierzonych prac. Cieszyła się naszymi sukcesami. Właściwie wszyscy możemy powiedzieć, że 
jesteśmy z niej, moje pokolenie i ci młodsi, i jeszcze młodsi, już nasi wychowankowie, bowiem wszyscy układamy się w linię generacyjną biorącą z niej swój naukowy początek. Utytułowani akademicko filmoznawcy rozsiani po różnych polskich, i nie tylko polskich, ośrodkach uniwersyteckich to w przeważającej mierze jej wychowankowie. Wypromowała Bóg wie ilu magistrantów i około pięćdziesięciu doktorów, to z pewnością rekord krajowy i europejski. Po obronie pracy habilitacyjnej zwykle przechodziła z habilitantem na "ty", skazując delikwenta na męki długiego przyuczania się do mówienia do niej „Alicjo”.

W końcu lat 70. XX w. Pani Profesor prowadziła na Uniwersytecie Jagiellońskim pierwsze feministyczne seminarium magisterskie i patriarchalny Uniwersytet jakoś to dzielnie wytrzymał. Za sprawą tych zajęć mój świat i jeszcze kilkunastu innych dziewcząt już na zawsze uległ przewartościowaniu, a kino nigdy nie było takie samo jak wcześniej.

O śmierci Pani Profesor powiadomiła mnie telefonicznie przyjaciółka $\mathrm{z}$ dawnego fraucymeru, płakała i powtarzała w rozpaczy: To niemożliwe, Pani Profesor była niezniszczalna, niezniszczalna, zawsze była, nie mogła odejść... A jednak odeszła... Przygotowała nas na swoje odejście. Wyprowadziła się do Hiszpanii w okolice Alicante, nad morze, gdzie powietrze jest krystalicznie czyste i łatwiej jej się oddychało - Kraków dławił ją spalinami. Wyjechać to trochę umrzeć - stwierdził francuski humorysta Alphonse Allais. Listy nie mogły w pełni zastąpić bezpośredniego kontaktu z błyskotliwa, czarującą kobietą. W miarę rozwoju choroby stawało się coraz bardziej pewne, że Pani Profesor już nie wróci do Krakowa, by znowu zamieszkać „na Alejach”. Z jej odejściem skończyła się epoka w polskim filmoznawstwie i w naszym życiu.

Gdzie teraz mieszkasz, Alicjo?...

\section{Grażyna Stachówna}

Keywords:

Alicja Helman
Profesorka nadzwyczajna w Instytucie Sztuk Audiowizualnych Uniwersytetu Jagiellońskiego, autorka pięciu książek oraz ponad dwustu artykułów na temat filmu powszechnego i polskiego, redaktorka jedenastu tomów zbiorowych. Obecnie professor emerita - wreszcie może w pełni robić tylko to, co naprawdę lubi: kończy pisać ostatni rozdział książki fańcioland $i$ okolice poświęconej filmom Jana Jakuba Kolskiego, ogląda filmy tylko z happy endem i tasiemcowe seriale, czyta grube powieści kryminalne, pasjonuje się śledztwami Cormorana Strike’a, fanuje Benedictowi Cumberbatchowi, słucha belcantowych oper i Elvisa Presleya.

\author{
Abstract \\ Grażyna Stachówna
}

Alice Doesn't Live Here Anymore...

A Memory of Professor Alicja Helman (1935-2021). 